\title{
Field Trip A (23 September 2018): geology and geomorphology of Giessen and its surrounding areas
}

\section{Frank Volker and Stefanie Menges}

Institut für Geographie, Justus-Liebig-Universität Gießen, 35390 Gießen, Senckenbergstraße 1, Germany

Correspondence: $\quad$ Frank Volker (frank.volker@geogr.uni-giessen.de)

Relevant dates: $\quad$ Published: 20 August 2018

How to cite:

Volker, F., and Menges, S.: Field Trip A (23 September 2018): geology and geomorphology of Giessen and its surrounding areas, DEUQUA Spec. Pub., 1, 3-13, https://doi.org/10.5194/deuquasp-1-3-2018, 2018.

Abstract:

This field trip is intended to present an introduction to the geological and geomorphological evolution of Giessen and its surrounding areas (Fig. 1). The conference location of Giessen is located at the intersection of three major geological and morphological units: the Rheinisches Schiefergebirge (Rhenish Massif) to the west, the Hessische Senke (Hessian Depression) to the north and south and the Vogelsberg volcanic field to the east (Fig. 2).

The rocks of the Rheinisches Schiefergebirge (Rhenish Massif) were formed during Paleozoic times, in the context of the Variscan orogeny. Dominant rock types include graywacke, slate, quartzite, and limestone, as well as mafic and felsic volcanics and their related pyroclastics. The area north and south of Giessen is dominated by the Hessische Senke (Hessian Depression), a north-southtrending subsidence area with several individual deposit segments. Due to Cenozoic tectonic activity, the Hessian Depression can be regarded as a connecting segment between the prominent Upper Rhine Graben and the smaller graben structures of northern Germany, and this is also documented by less consolidated Tertiary and Quaternary sediments. Long-lasting subsidence of the Hessian Depression, however, is indicated by the presence of Permian and Mesozoic sedimentary rocks. Rotliegend rocks are present towards the southwest rim of the Vogelsberg volcanic field and the Hanau-Seligenstädter Senke. Minor occurrences of Zechstein rocks are exposed along the Lahn valley between Giessen and Marburg. Mesozoic strata are dominated by Buntsandstein and are widespread in the Marburg area, with Muschelkalk and Keuper rocks being restricted to small erosional remnants in tectonic graben structures. The area to the east of Giessen is dominated by the Miocene Vogelsberg volcanic field, where an estimated area of $2500 \mathrm{~km}^{2}$ is covered by volcanic rocks of varying thickness, the Vogelsberg thus being the largest volcanic field of central Europe. The field trip provides an introduction to the geology, earth history and geomorphological characteristics of Giessen and its surrounding areas. We will therefore encounter rocks that formed in distinct geodynamic environments and within a timespan of roughly $400 \mathrm{Ma}$ (Devonian to present).

Kurzfassung:

Die Exkursion bietet mit ihrem Routenverlauf und den ausgewählten Aufschlüssen eine Einführung in die vielgestaltige geologische und geomorphologische Entwicklungsgeschichte des Tagungsortes Gießen und seiner näheren Umgebung. Die Stadt Gießen liegt am Schnittpunkt dreier bedeutender geologischer und geomorphologischer Einheiten: im Westen das jungkänozoisch gehobene Rheinische 
Schiefergebirge, im Osten das ausgedehnte miozäne Vulkanfeld des Vogelsberges und dazwischen die $\mathrm{N}-\mathrm{S}$ verlaufende Hessische Senke mit ihren mesozoischen und känozoischen Sedimentfüllungen.

Die Gesteine des Rheinischen Schiefergebirges wurden im Paläozoikum gebildet und ihre Entstehung steht im engen Zusammenhang mit der Variszischen Orogenese. Die dominierenden Gesteinsarten umfassen, je nach Ablagerungsraum und plattentektonischer Position, Grauwacken, Tonschiefer, Quarzite, biogene Kalksteine sowie mafische und felsische Vulkanite mit ihren korrelaten Pyroklastika. Die heutige morphologische Ausgestaltung des Rheinischen Schiefergebirges ist zu einem großen Teil auf die quartärzeitliche Hebung zurückzuführen. Die Gebiete nördlich und südlich von Gießen werden von der Hessischen Senke dominiert, einem N-S verlaufenden Subsidenzgebiet mit mehreren individuellen Ablagerungsräumen. Der lang anhaltende Subsidenzcharakter wird belegt durch die Anwesenheit permischer und mesozoischer Sedimente. Gesteine des Rotliegend finden sich vereinzelt am SW-Rand des Vogelsbergs und in der Hanau-Seligenstädter Senke. Relikte von Zechstein-zeitlichen Gesteinen sind vereinzelt an den Lahnhängen zwischen Marburg und Gießen aufgeschlossen. Bei den mesozoischen Gesteinen dominieren die klastischen Abfolgen des Buntsandstein, die große Gebiete im Raum Marburg in charakteristischer Weise prägen. Im Känozoikum kam es dann zur Ausbildung des Europäischen Grabensystems, das vom Rhonegraben bis weit in die Nordsee reicht. In Mittelhessen führte dies zu einer Wiederauflebung der Subsidenz-Tektonik und zur Anlage mehrerer individueller Ablagerungsräume mit gering verfestigten tertiären und quartären Sedimenten. Die Hessische Senke kann somit als Bindeglied zwischen dem großen Oberrheingraben im Süden und den kleineren Grabenstrukturen im nördlichen Deutschland angesehen werden. Das Gebiet östlich von Gießen wird durch die miozänen Vulkanite des Vogelsbergs eindrucksvoll dominiert. Trotz intensiver Erosion im Neogen und Quartär bedecken die Vulkanite heute noch eine Fläche von etwa $2500 \mathrm{~km}^{2}$ und machen damit den Vogelsberg zum größten zusammenhängenden Vulkanfeld Mitteleuropas. Die Exkursion vermittelt somit einen Einblick in den vielgestaltigen Aufbau und die geomorphologischen Charakteristika des Tagungsortes Gießen und seiner näheren Umgebung. Im Verlauf der Exkursion werden Gesteine angetroffen, die in ganz unterschiedlichen geodynamischen Situationen entstanden sind und einen erdgeschichtlichen Zeitraum von etwa $400 \mathrm{Ma}$ (Devon bis Rezent) umfassen.

\section{The Rheinische Schiefergebirge (Rhenish Massif) to the west of Giessen}

Rocks of the present-day Rhenish Massif (RM) were formed from Silurian times up to the upper Carboniferous/early Permian, in close connection with the Variscan orogeny. Plate tectonic processes related to this major orogenic event included opening and closing of oceanic basins, terrane accretion, volcanism, sedimentation, orogenic folding and metamorphism as well as nappe formation. Major players included the Old Red Continent in the north, the Avalonia terrane, the Rhenohercynian and Rheic oceans and Gondwana further south (Fig. 3).

These processes led to a large number of sedimentary, magmatic and metamorphic rocks, each representing their depositional, facies and/or geodynamic characteristics and thus providing valuable information for the reconstruction of these geological processes in space and time. Not surprisingly, (para-)autochthonous and allochthonous units are found in close contact with each other. In addition to varying degrees of alteration and post-orogenic displacements, this may well explain the difficulties in reconstructing the Paleozoic geodynamic processes as well as some of the fierce discussions in the recent scientific literature (Eckelmann et al.,
2014; Dörr and Zulauf, 2012; Franke, 2012) and references therein). At the end of the Variscan orogenic processes, the RM suffered massive erosion of elevated regions and coeval filling of basin structures, resulting in a widespread peneplain during Permian times.

During the Mesozoic, most parts of the RM were situated above sea level and acted as source regions for clastic sediments in adjacent basins. It is worth mentioning that the region of the RM west of Giessen lacks Mesozoic cover.

Intensive chemical weathering during early Tertiary times is documented by thick clay-rich saprolite layers, locally capped/covered by intraplate volcanics (Eifel, Siebengebirge, Westerwald). These kaolinite-rich soils and saprolites, with locally preserved thicknesses of more than $150 \mathrm{~m}$, reflect the humid tropical climate conditions during their time of formation. Climate conditions subsequently changed towards semi-arid characteristics, resulting in areal denudation of unprotected land surfaces.

During the Quaternary, the RM was severely affected by periglacial processes as well as intense uplift (Fig. 4), with an accumulated maximum uplift of more than $250 \mathrm{~m}$ during the last 800000 years in the uplift center (Eifel area). These led to the present-day morphologic characteristics of the RM, 


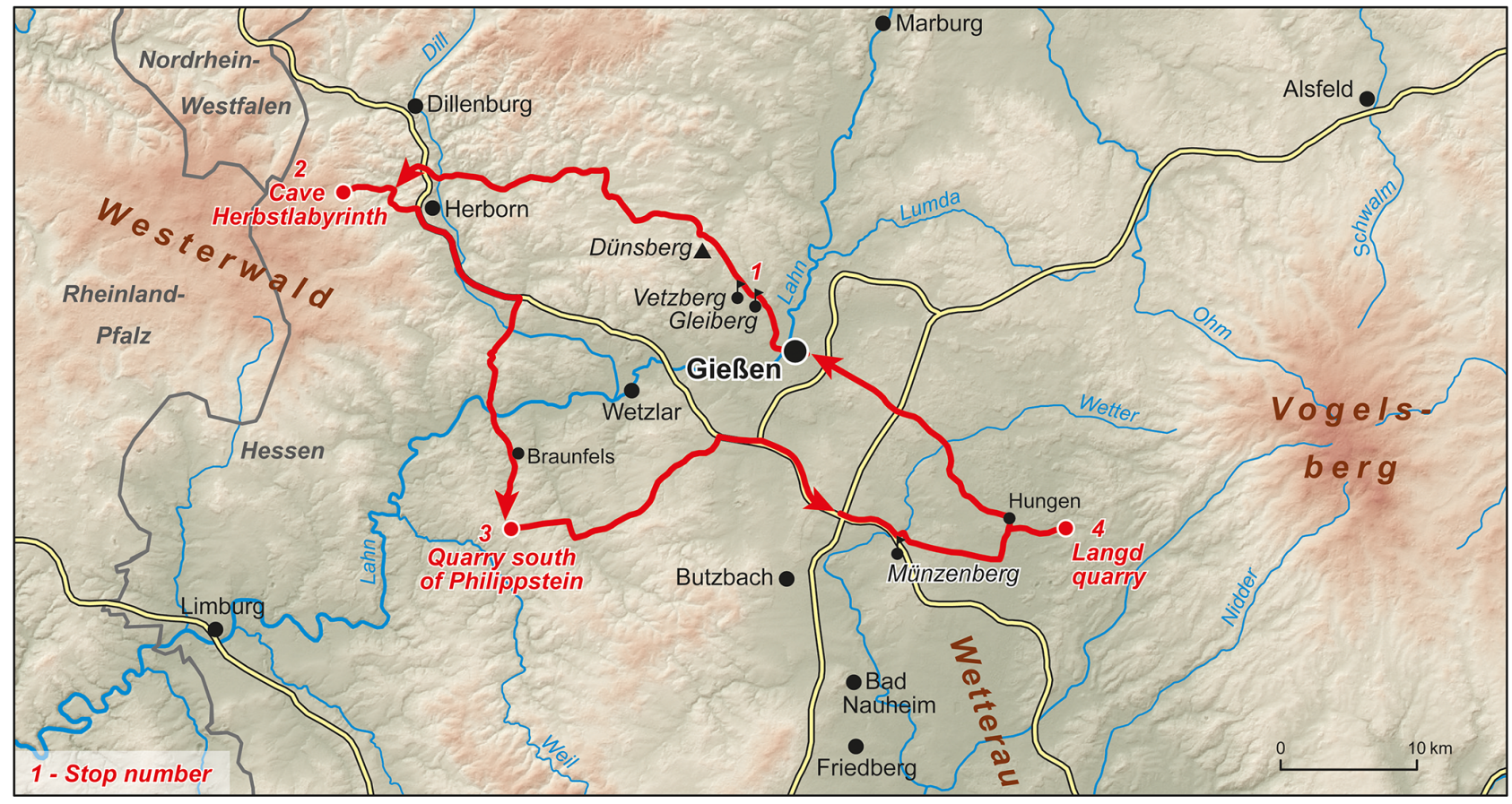

Figure 1. Topographic map with excursion route and major locations. Stop 1: Gleiberg and Vetzberg volcanoes, Stop 2: Herbstlabyrinth limestone cave, Stop 3: quarry south of Philippstein, Stop 4: abandoned quarry east of Langd.

i.e., a large uplifted block with plateau-like regions, maximum heights of around $900 \mathrm{~m}$ and deeply incised river valleys (e.g., Middle Rhine, lower Mosel and lower Lahn rivers).

Thus, morphologic processes during the Cenozoic are dominated by the following:

1. a phase of intense weathering and denudation during humid tropical and semi-arid climate conditions with peneplain formation

2. a phase of pronounced uplift and linear erosion during the Quaternary.

\section{Stop 1: Gleiberg - Tertiary volcanism and overview}

The old castle of Gleiberg (12th century) was built on a small hill ( $308 \mathrm{~m}$ a.s.l. and $70-80 \mathrm{~m}$ above the surrounding area). The hill is made up of Miocene columnar basaltic rocks that penetrate graywacke of lower Carboniferous age that are part of the Giessen nappe (Fig. 5).

Depending on weather conditions, this location and especially the castle keep offers a nice outlook and a panoramic view.

Towards the southeast, we look into the small depression of the Giessener Becken, with the foothills of the Vogelsberg in the distance.

To the east, we see the valley of the Lahn river, the corresponding main terrace and a prominent basalt hill (Lollarer
Kopf). In the far distance, though morphologically not very prominent, the forested slopes of the main Vogelsberg can be seen.

To the northeast, the Miocene basalt hill of Amöneburg and the Lahnberge of Marburg (early Mesozoic sandstone ridge) are visible.

To the north, behind the village of Krofdorf, there is a large forest area on comparatively infertile graywacke.

To the west, the plateau of Königsberg-Hohensolms, consisting of lower Carboniferous basaltic rocks that are locally known as "Diabas", can be seen.

To the northwest, a short distance from the prominent Dünsberg (498 ma.s.l.) is visible, a monadnock dominated by allochthonous lower Carboniferous lydite. In the foreground, Vetzberg and Köppel (Fig. 6), both volcanic edifices similar to Gleiberg (Weyl and Stibane, 1980) can be seen. It is worth noting that Gleiberg, Köppel and Vetzberg are aligned along a north-west-running fault line. Based on detailed geochemical and radiometric age studies by Turk et al. (1984), the location of Gleiberg, together with nearby Vetzberg and the small edifice of Köppel, comprise the westernmost eruption centers of the Vogelsberg volcanic field (VB). Columnar jointing is well developed at Vetzberg castle (Fig. 7).

Along the road from Gleiberg to Breitscheid (Stop 2), paleozoic rocks (dominantly graywacke, slate, diabase, limestone and also lydite) are exposed in numerous small quarries and roadside outcrops. Occasionally, a transformation of the 


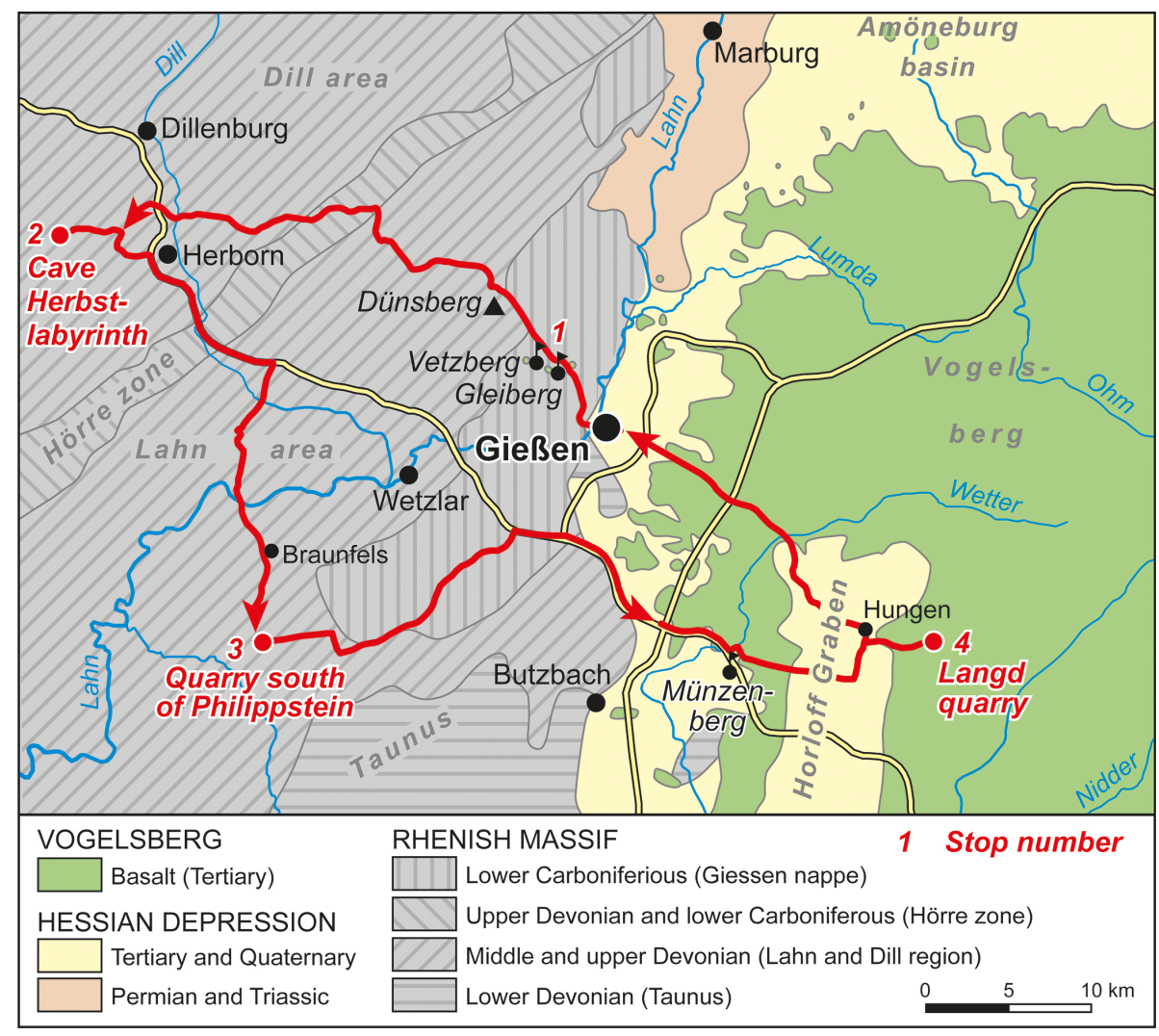

Figure 2. Simplified geological sketch map of Giessen and surrounding areas (modified from Weyl and Stibane, 1980). Stop numbers as in Fig. 1. Four principal units can be distinguished: (1) Paleozoic rocks of the Rhenish Massif, (2) Permian to Triassic sedimentary rocks, confirming long-lasting subsidence of the Hessian Depression, (3) less consolidated Tertiary and Quaternary sediments in north-southrunning subsidence segments (Amöneburger Becken, Horloff-Graben), thus connecting the prominent Upper Rhine Graben with the smaller graben structures of northern Germany and (4) Miocene Vogelsberg volcanic rocks, with numerous erosional remnants of various sizes along the present-day rim of the volcanic field.

silicate rocks into clay minerals is clearly visible. The formation of these clay minerals (kaolinite, illite) is attributed to intense chemical weathering during lower Tertiary and Miocene times (Felix-Henningsen, 1994). In adjacent areas of the Westerwald volcanic field, these clay-rich lithologies were covered by upper Tertiary volcanic rocks, resulting in an effective protection blanket against further weathering and especially erosion. Therefore, these clay deposits were to become the primary commodity for the famous ceramic industry in the Westerwald area, known as the "Kannenbäckerland".

\section{Stop 2: Breitscheid - Devonian limestone and recent karst}

\subsection{Mid-Devonian limestone}

Large limestone areas within the Rhenish Massif are genetically related to reef-building organisms, which include stromatoporoids, brachiopods, crinoids, bryozoa, echinoderms and others. Distribution of Devonian limestone within the
Rhenish Massif clearly reflects two different paleomorphologic situations: shallow waters close to the northern shoreline, and submarine swells within the deeper parts of the ocean, created by volcanic edifices (Figs. 8, 9). Reef growth was further supported by the low-latitude position of the area during Devonian times (Fig. 3).

Volcanic activity, especially pronounced towards the end of the Mid-Devonian, created volcanic swells of different sizes, which occasionally reached the water surface, thus creating small ocean islands and related atoll-like structures.

During the subsequent upper Devonian, most reef-building organisms died, in relation to the Kellwasser event, a period of worldwide mass extinction.

Ancient karst phenomena in this limestone indicate uplift events some time after the end of the reef-building phases, and examination of sedimentary input in karst cavities revealed both upper Devonian and lower Carboniferous ages (Flick, 2010).

Recent carbonate solution and calcite precipitation is indicated by several characteristic features, including ponors, dolines and speleothems in limestone caves. 


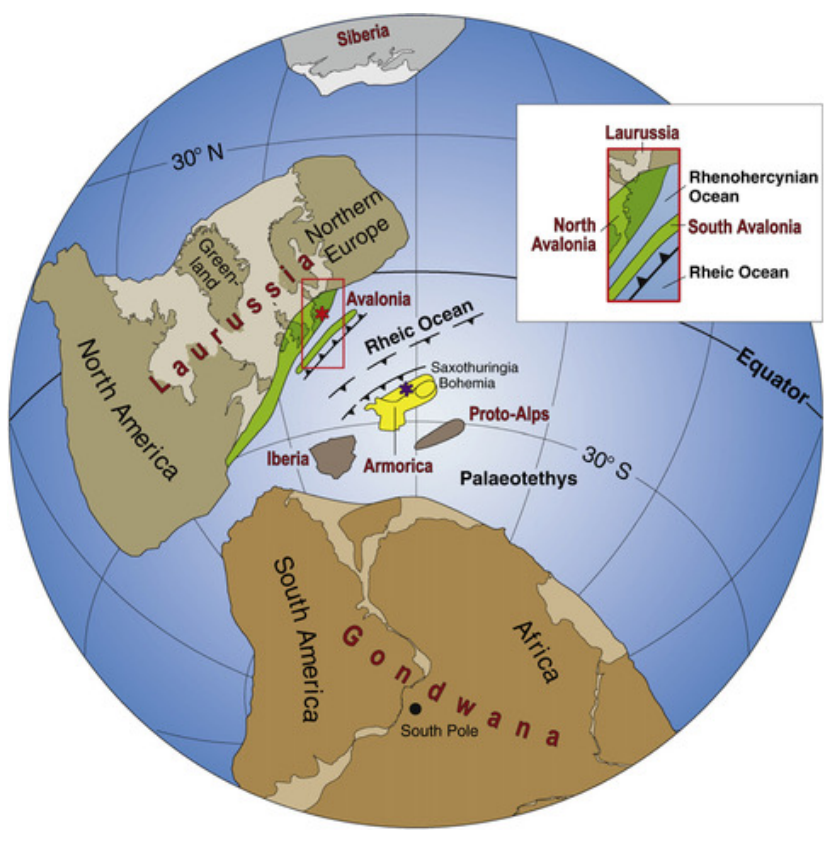

Figure 3. Plate tectonic reconstruction for the Late Devonian to early Carboniferous (Eckelmann et al., 2014). Red star: position of the autochthonous Rhenish Massif. Blue star: source area of the nappe units in the southeast of the Rhenish Massif.

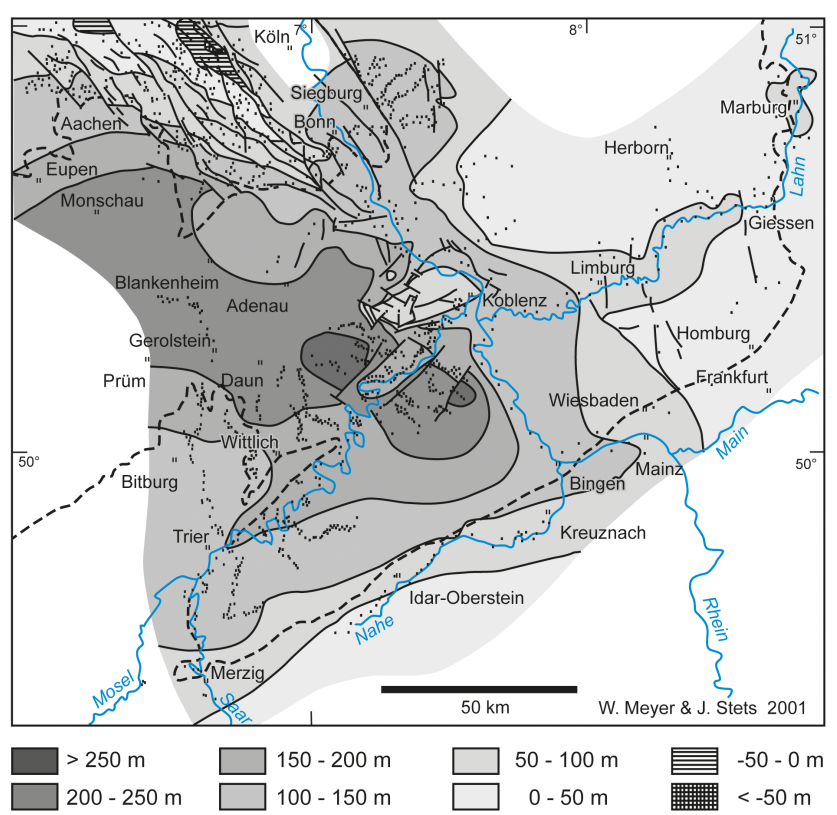

Figure 4. Sketch map showing the uplift of the Rhenish Massif during the last 800000 years (from Meyer and Stets, 2002). Small dots: observation points along rivers. Dashed line: the outer rim of the Rhenish Massif.

\subsection{The limestone caves Herbstlabyrinth and Adventhöhle}

Both limestone caves are situated between the villages of Breitscheid and Erdbach, within the eastern part of the Rhenish Massif, about $40 \mathrm{~km}$ northwest of Giessen. The cave system as it is currently known has a total length of more than $11 \mathrm{~km}$, documented by intensive speleological studies during the last decade (Dorsten et al., 2016). It is by far the largest cave system in Hesse.

This segment of the Rhenish Massif is characterized by two belts of the Mid-Devonian massive limestone occurrences, both showing an alignment of southwest-northeast, as shown in Fig. 9. In the northern belt, the former reefs reflect shallow water conditions on the shelf segment of the Old Red Continent. In the region of the Lahn-Dill synclines, submarine volcanoes formed shallow ridges and shoals that allowed atoll-like reefs to grow surrounded by deep-water conditions (Flick, 2010). The Herbstlabyrinth and Adventhöhle cave system is located in the Dill syncline (Fig. 8).

The landscape between Breitscheid and Erdbach shows characteristic features of limestone karst areas, e.g., dolines, sinkholes, karst springs and dry valleys. The limestone has been quarried for several decades, and it was on $11 \mathrm{De}-$ cember 1993 in the limestone quarry Medenbach (Holcim $\mathrm{GmbH}$ ) that members of the local Speläologische Arbeitsgemeinschaft Hessen (SAH) discovered the entrance to a cave that was named "Advent cave". In the following year, and close to the Advent cave, the access to another cave system was discovered by SAH, which was to become the Herbstlabyrinth. Recent speleological studies focus on the exploration and survey of newly discovered cave segments (currently known extension ca. $11.5 \mathrm{~km}$; Dorsten, 2017). These field studies are accompanied by detailed work on the age determination of dripstone with the Th-U technique (Mischel et al., 2017), the correlation of cave-forming processes with neotectonic events and dated river terraces and geochemical and stabile isotope studies on drip water and cryogenic calcite. For details of these ongoing studies see Mischel et al. (2017).

Since 2009, parts of the cave have been open to the public, within the framework of guided tours (Fig. 10).

\section{Stop 3: quarry south of Philippstein}

The quarry is located about $1 \mathrm{~km}$ south of the village of Philippstein. Exposed rocks are mafic volcanics of Givetium/Adorfium age (Middle to Early Upper Devonian; Deutsche Stratigraphische Gesellschaft, 2016) as well as red iron ore deposits (Fig. 11). At the eastern wall of the quarry, several galleries of the abandoned mine "Maria" have been cut off by quarry activities. All rock units were deformed during the Variscan orogeny.

In the lower parts of the quarry, columnar jointing is clearly visible. These flow units were then covered by vol- 


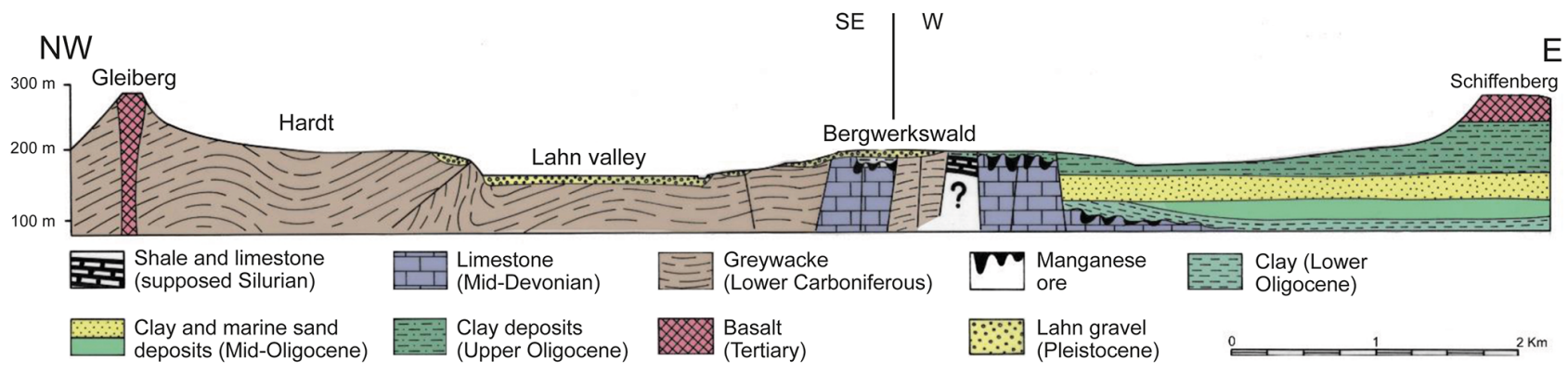

Figure 5. Simplified geological profile of the Giessen area (modified from Weyl and Stibane, 1980, composite from Gleiberg to Lahn valley and Giessen-Bergwerkswald northwest-southeast, and from Bergwerkswald to Schiffenberg west-east). The main petrographic units are shown: Paleozoic rocks of the Rhenish Massif (blue and gray), Cenozoic sedimentary filling of the north-south-trending subsidence (green and yellow) segments and Tertiary volcanics at the western border of the Vogelsberg volcanic field (purple).

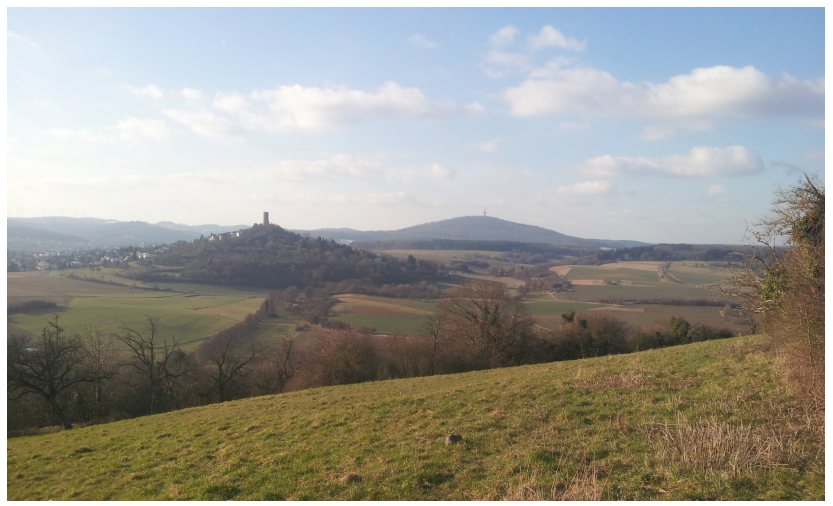

Figure 6. Typical landscape west of Giessen with Vetzberg (left) and Dünsberg (right). Own picture, 24 February 2018.

caniclastic lithologies (Nesbor, 2007). On top, the volcanics are present as pillow lavas, tubes and pillow fragments, indicating a submarine environment. Obviously, the lava split up into several lava tubes. Contact with seawater caused glassy rims, with the basaltic melt that is still hot flowing inside. Depending on the eruption rates, these lava tubes may have piled up to impressive volcanic masses.

The reddish iron ores belong to Lahn-Dill-type deposits, e.g., exhalative iron oxide mineralization associated with basaltic volcanic centers during Middle to Upper Devonian times (Von Raumer et al., 2017). In a first step, mobilization of $\mathrm{Fe}$ and associated $\mathrm{Ca}$ and $\mathrm{Si}$ was caused by hydrothermal alteration and leaching of subjacent submarine basaltic volcanics (Flick, 2010). Subsequently, the rising Fe-bearing hot fluids encountered cool oxidizing water, resulting in the precipitation of iron oxides and hydroxides. For a more detailed discussion of ore genesis in the RM, please see Von Raumer et al. (2017).

Iron ore mining in the Lahn-Dill ore district has been documented since the Celtic area, about 2000 years ago. Numerous $\mathrm{Fe}$ ore mines were operating during the 19th and

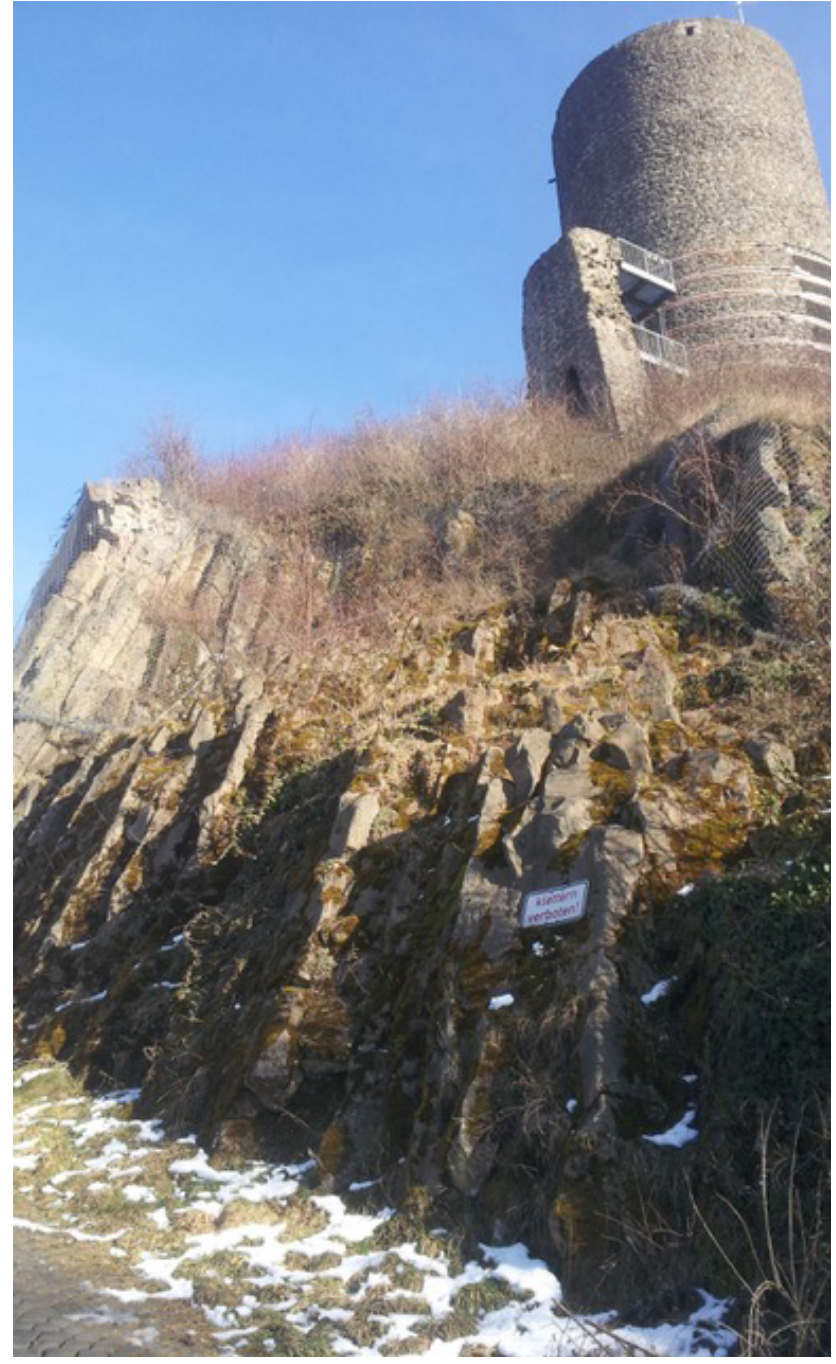

Figure 7. Miocene basaltic rocks with well-developed columnar jointing at Vetzberg castle. Own picture, 24 February 2018. 


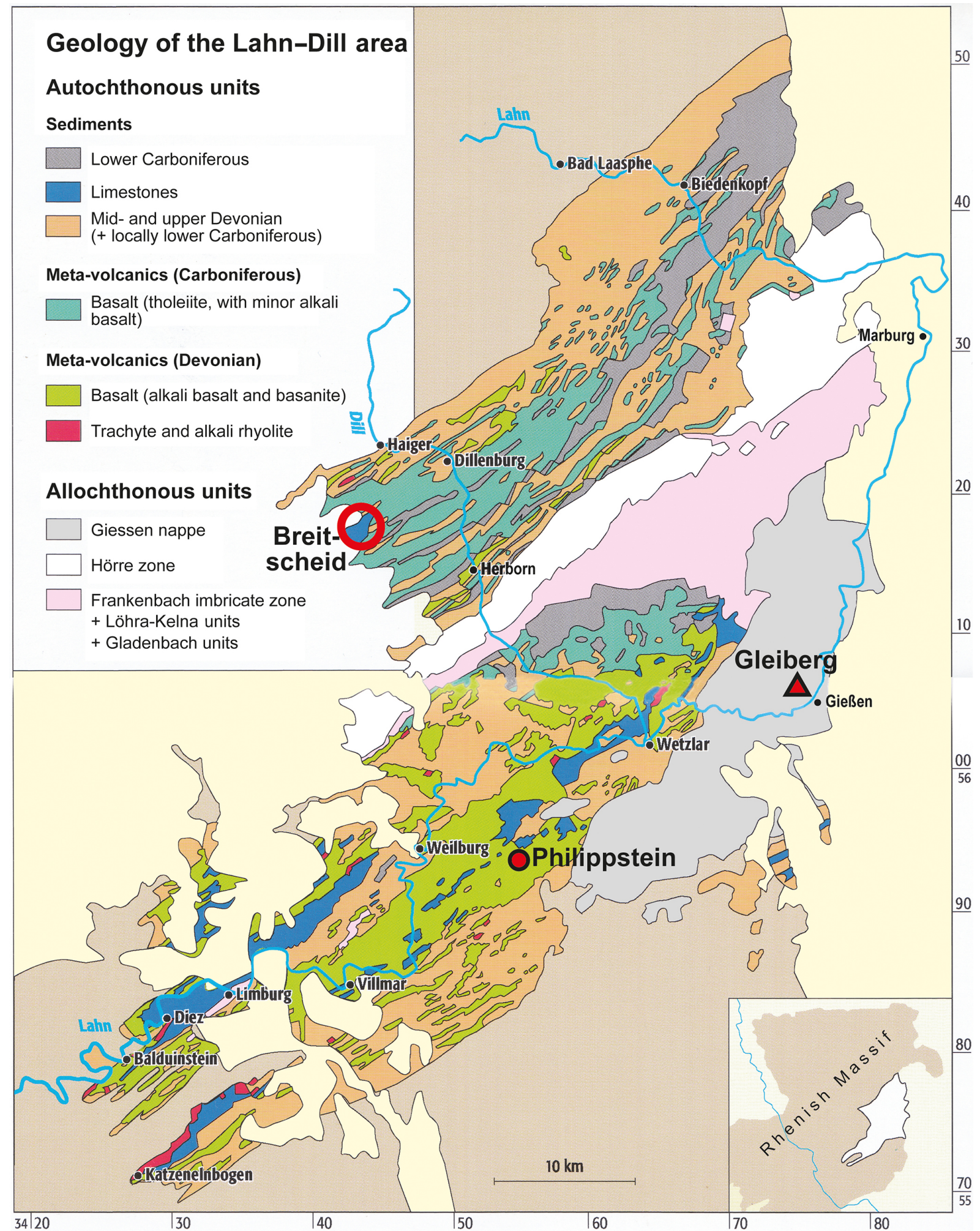

Figure 8. Simplified geological map, showing the Paleozoic autochthonous rock units of the Lahn-Dill region (from Flick, 2010, and references therein). Also shown are three allochthonous Paleozoic units (Giessen nappe, Hörre zone, Frankenbach imbricate zone). Red triangle: Gleiberg castle (Stop 1). Red circle: limestone of the Breitscheid area (Stop 2). Red dot: quarry south of Philippstein (Stop 3). 


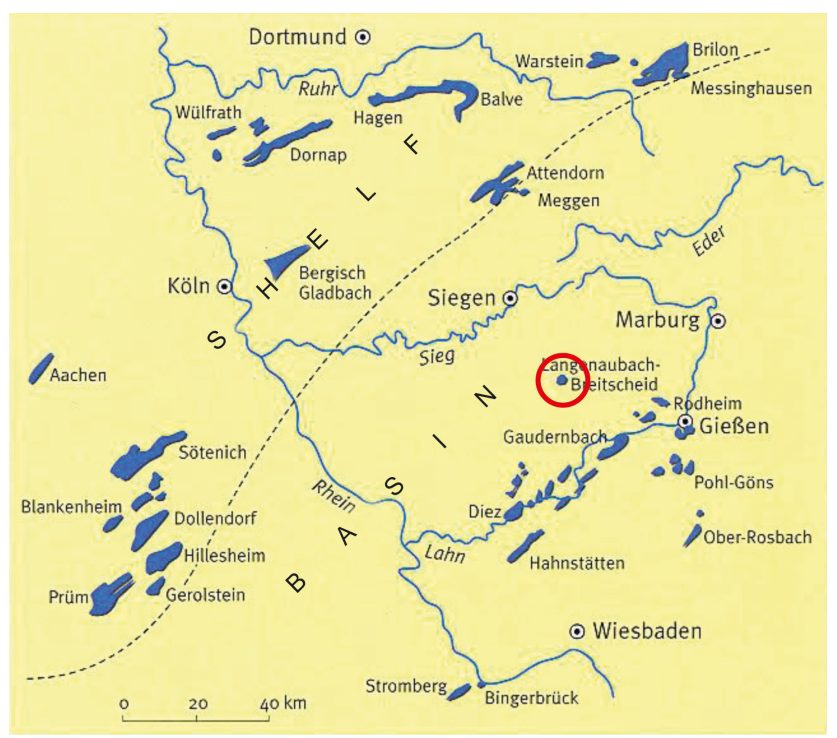

Figure 9. Distribution of Devonian limestone reefs within the Rhenish Massif (from Rothe, 2005). Reefs that developed on the shelf rim are located north of the stippled line. To the south of the stippled line, reefs grew on volcanic edifices that formed submarine rises and ridges. Breitscheid (Stop 2) is marked by a red circle.

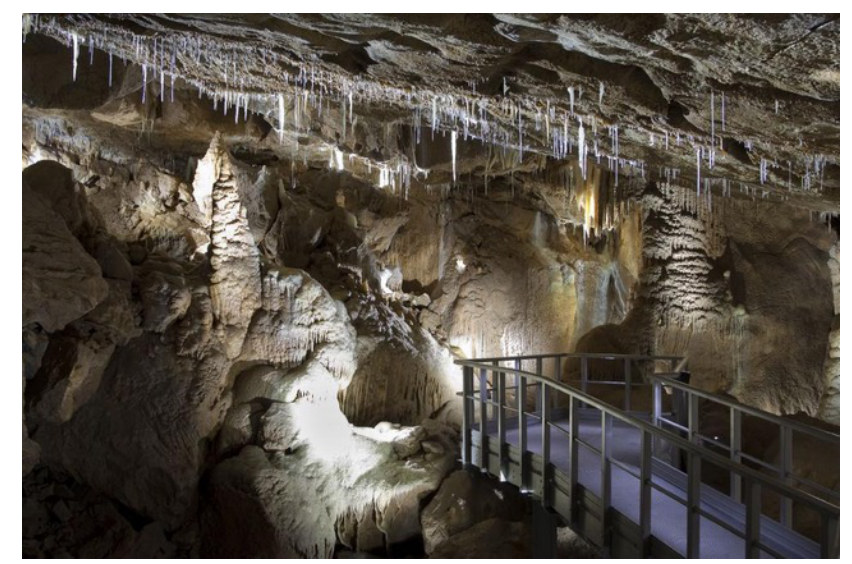

Figure 10. Inside the limestone cave Herbstlabyrinth, Breitscheid (Schauhöhle Herbstlabyrinth Breitscheid 2018, (C K. P. Kappest).

20th century. The last mine (Grube Fortuna north of SolmsOberbiel) was closed down in 1983.

\section{The Horloff-Graben (route from Philippstein (Stop 3) to Hungen-Langd (Stop 4))}

Several small basins and graben structures connect the morphologic end of the Upper Rhine Graben with the graben structures of northern Germany. These include the HanauSeligenstädter Senke, the Wetterau, the Horloff-Graben, the Giessener Becken and the Amöneburger Becken. Thus, unconsolidated sediments of Cenozoic age are widespread in the regions north and south of Giessen (Fig. 2). Pleistocene loess cover is most pronounced in the basin areas, e.g., Amöneburger Becken, Wetterau and Horloff-Graben (see Field Trip B for details).

It should be mentioned that, amongst these small subsidence structures, only the Horloff-Graben is of post-volcanic age. The morphologically well-defined Horloff-Graben incises into the southwestern section of the Vogelsberg, forming a north-south-running graben structure, $20 \mathrm{~km}$ long and $5 \mathrm{~km}$ wide (Figs. 2, 12). Graben sediments are of Pliocene and Pleistocene age, with several brown coal seams being developed within the Pliocene pile. Despite their very young age, those brown coal seams were extensively exploited underground and later on in open-pit mines. Mining activities ended in 1991. Subsequent flooding of the open pit gave rise to the so-called "Wetterauer Seenplatte", now widely used for local recreation, water sports and nature protection.

\section{The Vogelsberg volcanic field and internal structure}

$\mathrm{VB}$, located to the east of Giessen, was active during the Miocene. With an area of $2500 \mathrm{~km}^{2}$ and a total volume of at least $500 \mathrm{~km}^{3}$, it is considered the largest volcanic field by volume in central Europe (Reischmann and Schraft, 2009; Fig. 12).

Landscape structure of this huge volcanic field comprises four distinct units. The central parts are known as "Oberwald" above $600 \mathrm{~m}$ a.s.l. and "Hoher Vogelsberg" between 600 and $500 \mathrm{~m}$ (Leßmann et al., 2000). The "Unterer Vogelsberg" forms a zone of up to $20 \mathrm{~km}$ wide around the Hoher Vogelsberg. The volcanic layers extending to the northwest are known as the "Vorderer Vogelsberg". The Taufstein (774 $\mathrm{m}$ a.s.1.) and the Hoherodskopf $(764 \mathrm{~m})$ close by have the highest elevations.

Several boreholes provide important information on the minimum size and volume of VB volcanic rocks as well as the internal structures of the volcanic masses (Reischmann and Schraft, 2009). It should be emphasized, however, that the borehole "Forschungsbohrung Vogelsberg 1996", that penetrated the Central Part of the VB (Oberwald), did not reach the pre-volcanic basis, despite a total coring of $656 \mathrm{~m}$ of volcanic rocks. Thus the estimated volume of $500 \mathrm{~km}^{3}$ must be regarded as a minimum mass.

Those boreholes, in conjunction with detailed field and radiometric studies, reveal new insights into the genesis of this huge volcanic edifice. Vogelsberg volcanism comprised a main activity phase at 19-16 Ma and, separated by a period of magmatic quiescence, a final phase at around $14 \mathrm{Ma}$ (Nesbor, 2014; Abratis et al., 2015). Volcanism of the main phase started with basanitic to alkali basaltic magmas and pyroclastics, followed by dominantly trachytic rocks. Phreatomagmatic eruptions and maar structures occurred quite frequently (Nesbor, 2014). After a period of magmatic quies- 

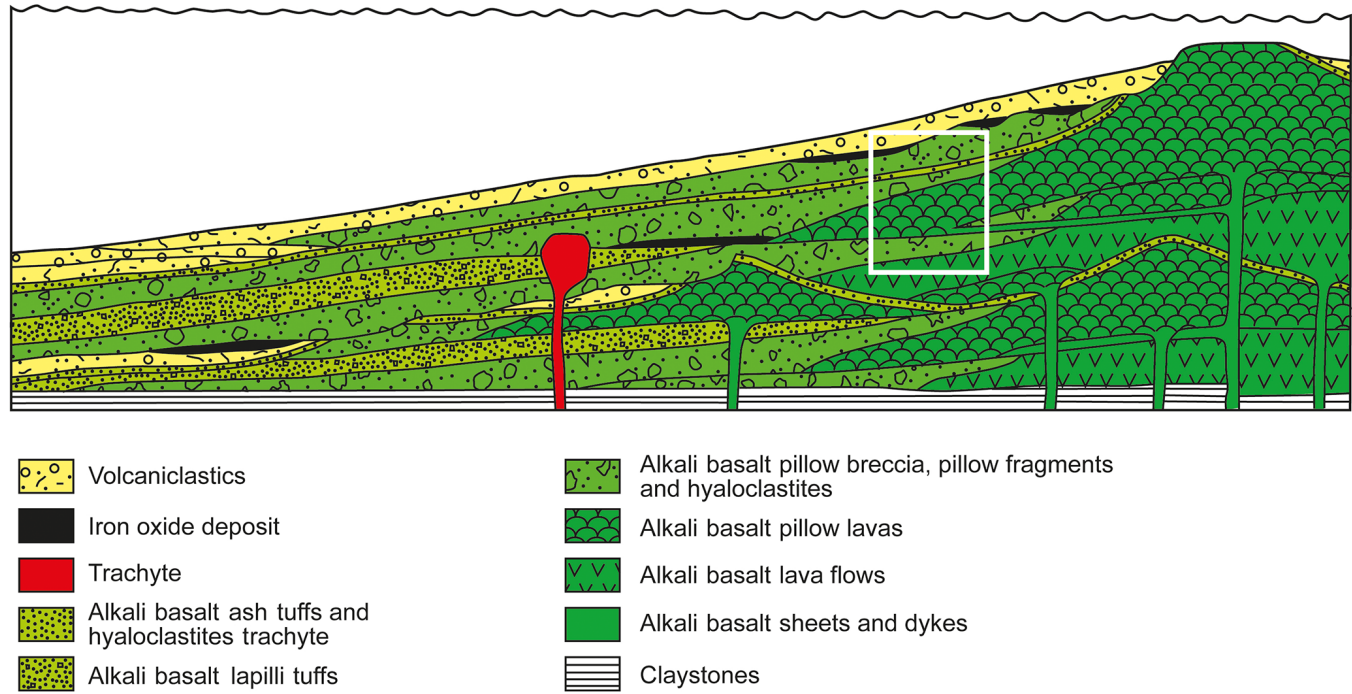

Alkali basalt pillow breccia, pillow fragments and hyaloclastites

Alkali basalt pillow lavas

$\checkmark \vee$ Alkali basalt lava flows

Alkali basalt sheets and dykes

Claystones

Figure 11. Schematic sketch map of a Devonian submarine volcanic edifice in the Lahn-Dill area (from Nesbor, 2007). White rectangle: segment exposed at the Philippstein quarry (Stop 3).

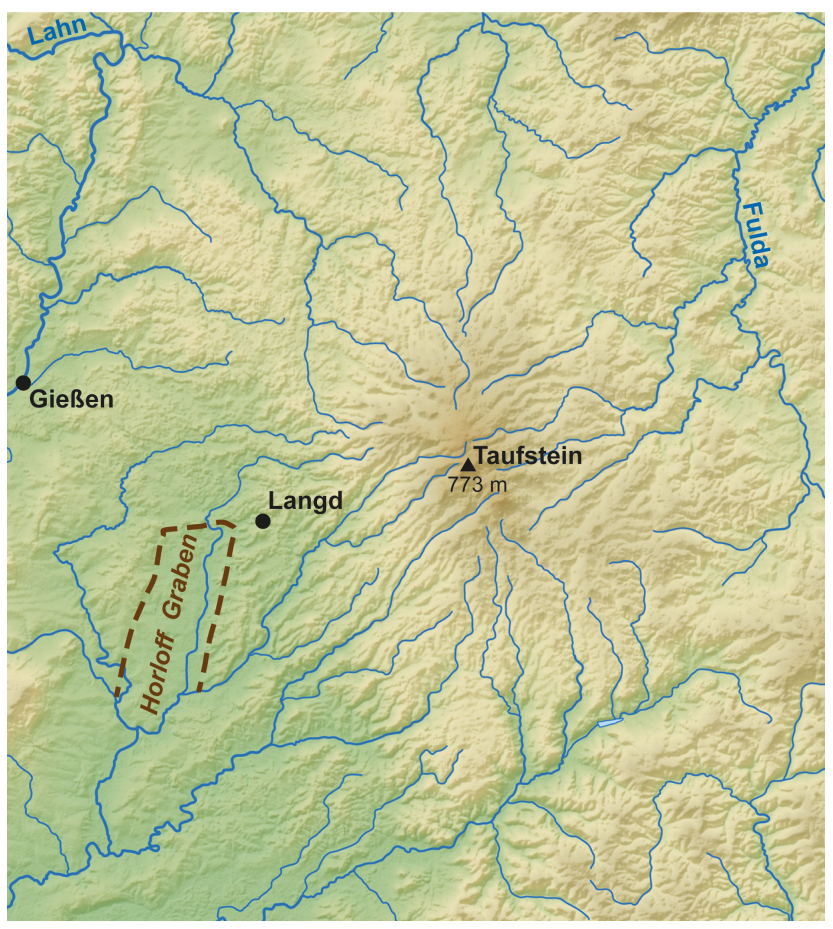

Figure 12. Morphological map of the Vogelsberg area, with the characteristic star-shaped drainage pattern. The highest point of the volcanic field (Taufstein) is indicated by the black triangle. The town of Giessen is also shown, as well as the post-volcanic HorloffGraben and Hungen-Langd (Stop 4).

cence, volcanic activity recommenced at about $14 \mathrm{Ma}$ with the eruption of alkali basaltic and basanitic lava flows, with eruption centers being essentially confined to the Oberwald region.
During the magmatic rest period, erosive and pedogenic processes dominated, causing leveling of volcanic edifices and a strong pedogenic overprint due to tropical-subtropical and humid climate conditions. These processes gave rise to a widespread erosional surface, which is still visible as a morphological step (Abratis et al., 2015).

Final volcanic activity was essentially concentrated in the central Oberwald region and dominated by low-viscosity mafic lava flows. Although volumetrically subordinate, these younger lava flows covered older volcanic sequences and erosional features. Due to a well-established climate change during the Langhian towards moderate and rather dry conditions, the final lava flows are much better preserved, thus giving the Vogelsberg volcanic field the appearance of a huge basaltic shield volcano (Nesbor, 2014).

The only rocks that are locally preserved are remnants of intense weathering of Vogelsberg volcanic rocks during Burgidalian times, e.g., Fe-rich crests and saprolite, the latter with thicknesses of more than $50 \mathrm{~m}$ (Schwarz, 1997) and most likely related to the mid-Miocene Climate Optimum.

Taking into account the field evidence from the Rhenish Massif to the west, we can emphasize two Cenozoic periods of intense chemical weathering, e.g., a lower Tertiary period, documented in widespread kaolinization of Paleozoic rocks, and a mid-Miocene period, which created Fe crests and saprolite on Vogelsberg volcanics that are 19-16 Ma old.

\section{Stop 4: abandoned small quarry, close to Hungen-Langd}

The old quarry is located about $500 \mathrm{~m}$ east of Hungen-Langd and provides an excellent view into the internal structure of 


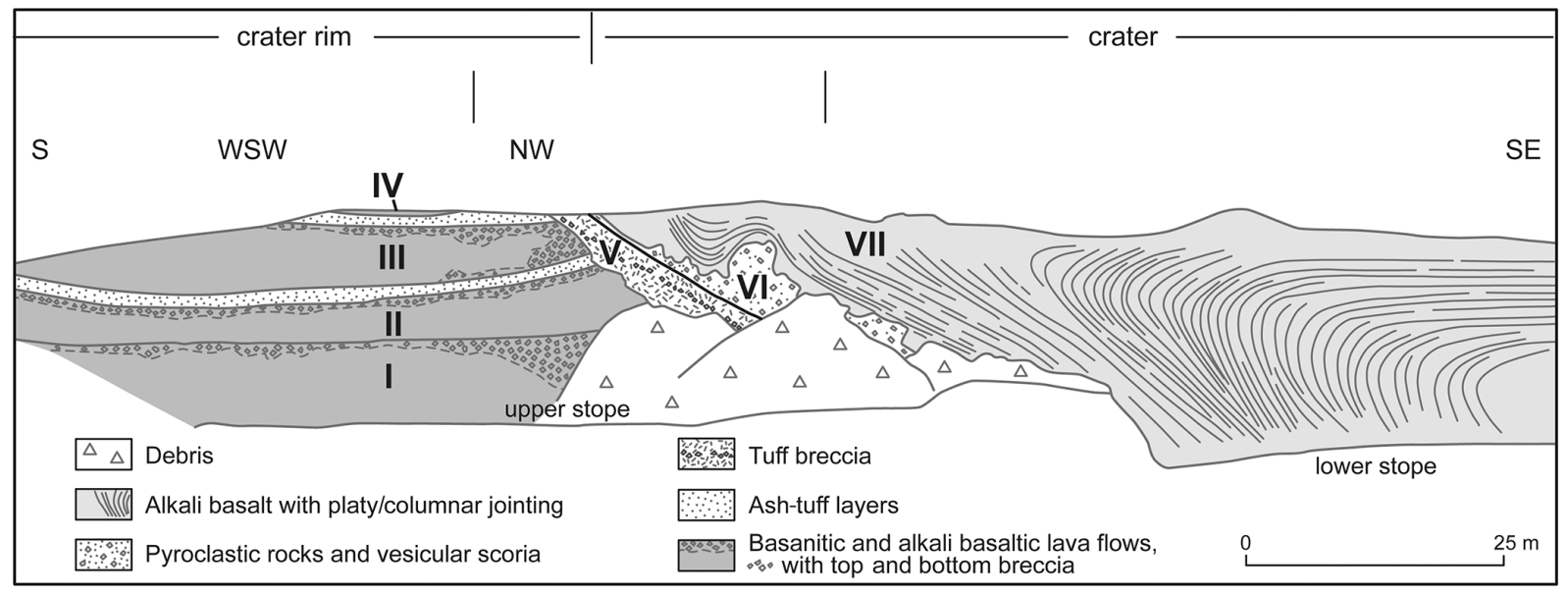

Figure 13. Abandoned quarry, about $500 \mathrm{~m}$ east of Hungen-Langd (Stop 4) (modified from Nesbor, 2014). Composite sketch map of the quarry walls. Western segment: four lava flows (unit I to IV), each between 5 and $8 \mathrm{~m}$ thick, with well-developed breccia zones at their basis and upper regions. Intercalated between the lava flows are tuff layers, dominated by mafic ash and fragments of country rock. Central part: pyroclastic unit (unit V), about $4 \mathrm{~m}$ thick, cutting the lava flows and dipping ca. $45^{\circ}$ towards southeast, dominated by tuff breccia that contains basanitic blocks, up to $1 \mathrm{~m}$ in size. Lapilli-size particles of the tuff breccia show very few vesicles. Unit VI: 1 to $4 \mathrm{~m}$ of pyroclastics with different properties, overlying unit $\mathrm{V}$, characterized by highly vesicular scoria, embedded in a lapilli and ash matrix. Eastern segment: massive alkali basalts (unit VII), overlying the pyroclastic sequences, with clearly visible platy and columnar jointing.

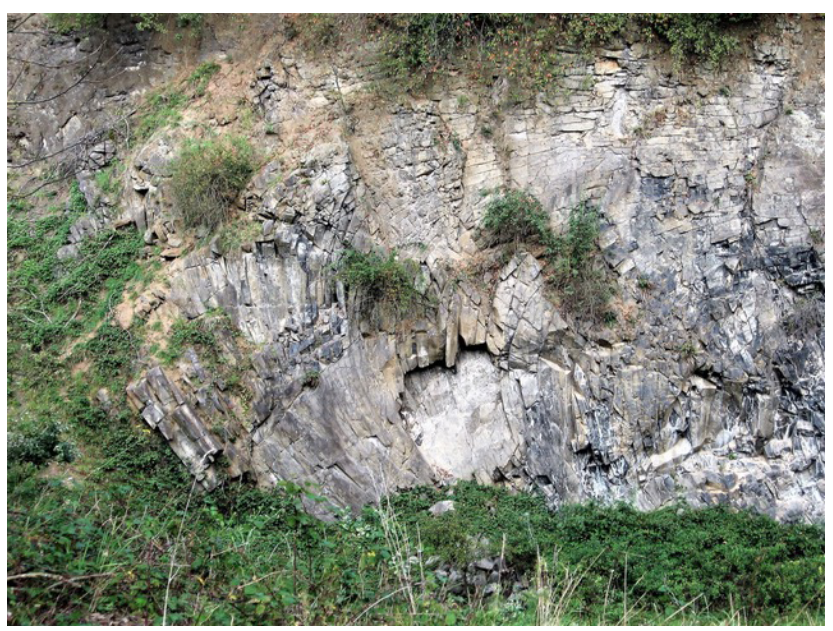

Figure 14. Columnar jointing in former lake lava, eastern segment of the old quarry, Hungen-Langd (Stop 4). Stefan Schorn, (C) Reinhold, 20 March 2017.

the Vogelsberg volcanic edifice (Ebhardt et al., 2001; Nesbor, 2014; Reischmann and Schraft, 2009).

In the western segment of the quarry, four lava flows of basanitic to alkali-basaltic composition are exposed, each between 5 and $8 \mathrm{~m}$ thick, with well-developed breccia zones at their basis and upper regions (Fig. 13). Intercalated between the lava flows are tuff layers, which are dominated by mafic ash and fragments of country rock (e.g., Buntsandstein). Thus, volcanic activity included both effusive and explosive characteristics.
In the eastern part of the quarry, the lava flows were blown away by a younger explosive event which created a crater wall with a dip of ca. $45^{\circ}$ towards southeast. Pyroclastic rocks closest to the crater wall are dominated by tuff breccia that contain basanitic blocks, up to $1 \mathrm{~m}$ in size. Lapilli-size particles of the tuff breccia show very few vesicles. Thus the crater-forming event is most likely due to the interaction of rising hot mafic magma with groundwater at shallow depth, causing a phreatomagmatic explosion that destroyed the lava flows and created a maar-type conical crater.

The initial maar deposits are overlain by ca. 1 to $4 \mathrm{~m}$ of pyroclastics with different properties. This sequence is characterized by highly vesicular scoria, embedded in a lapilli and ash matrix. Obviously there was a change in eruptive behavior towards lava fountains and effective degassing, most probably related to a lack of groundwater supply.

The volcanic rocks that rest on this layer of highly vesicular scoria occupy the entire eastern section of the quarry. They consist of massive alkali basalts with clearly visible platy and columnar jointing due to comparatively slow cooling and shrinking (Fig. 14). This is best explained by further magma supply from below, ongoing degassing and prohibited groundwater influx, resulting in a slowly cooling lava lake that completely filled the conical crater structure.

Data availability. No data sets were used in this article. 
Author contributions. Frank Volker wrote the text and participated in the fieldwork. Stefanie Menges participated in the fieldwork and took the photographs of Figs. 6 and 7.

Competing interests. The authors declare that they have no conflict of interest.

Acknowledgements. We are much indebted to Lisett Diehl (Geography Dept.) who prepared and improved several figures. We gratefully acknowledge constructive comments of an anonymous reviewer. Finally we want to thank the numerous earth scientists who, over the decades, and step by step, have provided important and detailed components of the complex and highly varied geology that characterizes Giessen and its surrounding areas.

\section{References}

Abratis, M., Viereck, L., Büchner, J., and Tietz, O.: Route to the Volcanoes in Germany - conceptual model for a geotourism project interconnecting geosites of Cenozoic volcanism, Zeitschrift der Deutschen Geologischen Gesellschaft, 166, 161185,2015 .

Deutsche Stratigraphische Gesellschaft: Stratigraphische Tabelle von Deutschland, edited by: Koordination und Gestaltung: Menning, M. and Hendrich, A., 2. Aufl., available at: http://www. stratigraphie.de/std/Bilder/5_2.pdf (last access: 1 July 2018), 2016.

Dörr, W. and Zulauf, G.: Reply to W. Franke on W. Dörr and G. Zulauf elevator tectonics and orogenic collapse of a Tibetan-style plateau in the European Variscides: the role of the Bohemian shear zone, Int. J. Earth Sci., 101, 2035-2041, 2012.

Dorsten, A., Dorsten, I., Finke, M., Meyer, S., and Zaenker, S.: Das Herbstlabyrinth und der Karst in Breitscheid im Westerwald, edited by: Speläologische Arbeitsgemeinschaft Hessen e.V. (SAH), 2. Aufl., Breitscheid, 2016.

Dorsten, I.: Karst und Höhlen: Die faszinierende Unterwelt der Riffkalke um Breitscheid und ihre Bedeutung als Klimaarchive, in: Riffe, Vulkane, Eisenerz und Karst im Herzen des Geoparks Westerwald-Lahn-Taunus, edited by: Henrich, R., Bach, W., Dorsten, I., Georg, F.-W., Henrich, C., and Horch, U., Wanderungen in der Erdgeschichte, 33, 81-92. Pfeil-Verlag, München, Deutschland, 2017.

Ebhardt, G., Ehrenberg, K.-H., Hottenrott, M., Kött, A., Leßmann, B., and Nesbor, H.-D.: Geologie und Hydrogeologie des südwestlichen Vogelsbergs und seiner Umrahmung, Jahresberichte und Mitteilungen des Oberrheinischen Geologischen Vereins, Neue Folge, 83, 65-87, 2001.

Eckelmann, K., Nesbor, H.-D., Königshof, P., Linnemann, U., Hofmann, M., Lange, J.-M., and Sagawe, A.: Plate interactions of Laurussia and Gondwana during the formation of Pangaea Constraints from U-Pb LA-SF-ICP-MS detrital zircon ages of Devonian and Early Carboniferous siliciclastics of the Rhenohercynian zone, Central European Variscides, Gondwana Res., 25, 1484-1500, 2014.
Felix-Henningsen, P.: Mesozoic-Tertiary weathering and soil formation on slates of the Rhenish Massif, Germany, Catena, 21, 229-242, 1994.

Flick, H.: Lahn-Dill-Gebiet, Quelle \& Meyer - Verlag, Wiebelsheim, 2010.

Franke, W.: Comment on Dörr and Zulauf: Elevator tectonics and orogenic collapse of a Tibetan-style plateau in the European Variscides: the role of the Bohemian shear zone, Int. J. Earth Sci., 101, 2027-2034, 2012.

Leßmann, B., Scharff, H.-J., Wedel, A., and Wiegand, K.: Grundwasser im Vogelsberg, Hessisches Landesamt für Umwelt und Geologie, Wiesbaden, 2000.

Meyer, W. and Stets, J.: Pleistocene to Recent tectonics in the Rhenish Massif (Germany), Neth. J. Geosci., 81, 217-221, 2002.

Mischel, S. A., Scholz, D., Spötl, C., Jochum, K. P., SchröderRitzau, A., and Fiedler, S.: Holocene climate variability in Central Germany and a potential link to polar North Atlantic: A replicated record from three coeval speleothems, The Holocene, 27, 509-525, 2017.

Nesbor, H.-D.: Paläozoischer Vulkanismus im Lahn-Dill-Gebiet - südöstliches Rheinisches Schiefergebirge, Jahresberichte und Mitteilungen des Oberrheinischen Geologischen Vereins, Neue Folge, 89, 193-216, 2007.

Nesbor, H.-D.: Der Vogelsberg - Vulkanologische und petrographische Entwicklung eines großen miozänen IntraplattenVulkangebiets in Mitteleuropa, EDGG, 252, 22-39, 2014.

Reischmann, T. and Schraft, A.: Der Vogelsberg - Geotope im größten Vulkangebiet Mitteleuropas, Hessisches Landesamt für Umwelt und Geologie, Wiesbaden, 2009.

Rothe, P.: Die Geologie Deutschlands, Primus-Verlag, Darmstadt, 2005.

Schorn, S.: () Reinhold, 20 March 2017, Source: MineralienatlasFossilienatlas: Deutschland/Hessen/Gießen, Bezirk/Gießen, Landkreis/Hungen/Langd/Steinbruch Maykranz (last access: 1 July 2018), 2017.

Schwarz, T.: Lateritic bauxite in central Germany and implications for Miocene palaeoclimate, Palaeogeogr. Palaeocl., 129, 37-50, 1997.

Turk, P.-G., Lohse, H.-H., Schürmann, K., Fuhrmann, U., and Lippolt, H. J.: Petrographische und Kalium-Argon-Untersuchungen an basischen tertiären Vulkaniten zwischen Westerwald und Vogelsberg, Geol. Rundsch., 73, 599-617, 1984.

Von Raumer, J. F., Nesbor, H.-D., and Stampfli, G. M.: The northsubducting Rheic Ocean during the Devonian: consequences for the Rhenohercynian ore sites, Int. J. Earth Sci., 106, 2279-2296, 2017.

Weyl, R. and Stibane, F.: Geologischer Führer Gießen und Umgebung, 2. Aufl., Mittelhessische Druck- und Verlagsgesellschaft, Gießen, 1980. 